Fatal

Advice 


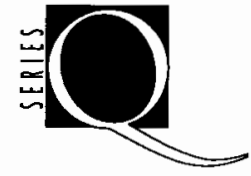

Edited by Michèle Aina Barale, Jonathan Goldberg,

Michael Moon, and Eve Kosofsky Sedgwick 

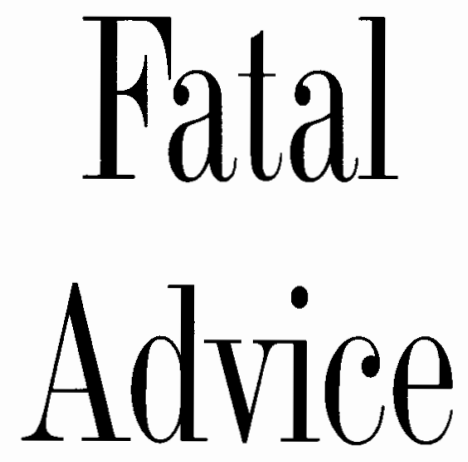

HOW SAFE-SEX EDUCATION WENT WRONG

\section{Cindy Patton}

Duke University Press Durham and London

1996 
(C) 1996 Duke University Press

All rights reserved

Printed in the United States of America on acid-free paper $\infty$

Typeset in Times Roman with Modern Torino display

by Keystone Typesetting, Inc.

Library of Congress Cataloging-in-Publication Data

appear on the last printed page

of this book. 
Want to know a dirty little secret?

Condoms don't save lives.

But restraint does.

Only fools think condoms are foolproof.

Remember, better safe than sorry.

Some common sense and a public service announcement from the Catholic League for Religious and Civil Rights

IO I I First Avenue, New York, NY 10022

(2I2) 37 I-3I9I

Advertisement in the New York City subways appearing in June 1994, during the celebration of the 25th anniversary of the Stonewall riots, which sparked the contemporary gay liberation movement. 
